\title{
The Academic Agenda on Training Teachers in Brazil
}

\author{
Rosimar Serena Siqueira Esquinsani ${ }^{1}$, Valdocir Antonio Esquinsani² \\ ${ }^{1}$ Graduate Program in Education, Faculty of Education, University of Passo Fundo, Passo Fundo, Brazil \\ ${ }^{2}$ Institute of Philosophy and Human Sciences, University of Passo Fundo, Passo Fundo, Brazil \\ Email: rosimaresquinsani@upf.br
}

How to cite this paper: Esquinsani, R. S. S., \& Esquinsani, V. A. (2016). The Academic Agenda on Training Teachers in Brazil. Creative Education, 7, 2088-2093. http://dx.doi.org/10.4236/ce.2016.715208

Received: May 31, 2016

Accepted: September 10, 2016

Published: September 13, 2016

Copyright $\odot 2016$ by authors and Scientific Research Publishing Inc. This work is licensed under the Creative Commons Attribution International License (CC BY 4.0).

http://creativecommons.org/licenses/by/4.0/

\begin{abstract}
Considering the importance of the movements on teacher training in Brazil, the text seeks to map the academic agenda or the scientific literature on the subject. To do so, it is based in a longitudinal survey on the main trends of research in the area of teacher training over the first fifteen years of the 21st century (2001-2015), locating and examining 142 scientific articles published in recognized Brazilian journals in the educational area. It describes aspects of form and content of those articles, indicating how the national scientific production has behaved on the subject. It concludes that there are gaps in the studies, such as teacher training for early childhood education and acting in private schools, as well as the existence of a gap regarding the theoretical references used.
\end{abstract}

\section{Keywords}

Teacher Training, Educational Politics, Educational Agenda

\section{Introduction}

Considering the importance of the movements on teacher training in Brazil-especially the texts of Resolution CP/CNE 2, from 1 July 2015, and the Law 13,005/2014 (PNEPlan National of Education law) (Brazil, 2015), the article seeks to map the academic agenda on the subject, from the analysis of scientific papers, understood as representation of scientific issues and emerging conceptual frameworks.

To be more strategic, the text discusses the training of teachers working in basic education because in Brazil there are, by virtue of Law 9.394/1996, two levels of education: basic education and higher education (Brazil, 1996: Article 21).

The choice of approach to the subject across scientific articles is a part, still, at belief that scientific papers are the communication between science and the public, stimulating 
approximations between the science and civil society.

The communication between scientists and their public can be held formally or informally in society. Informal communications are those, ephemeral by definition, as is the case of information transmitted through speech at congresses and conferences. The formal communication has a longer life and concentrates on books, journals and reports (Almeida, 2010: p.222).

Thus to expose ideas in a scientific journal, the researcher-author is communicating results of their studies, indicating theoretical and methodological paths taken and informing progress on the subject to search.

Finally, we must inform that the text presented is part of the partial results of a survey that aims to establish discussion about the concepts and procedures inherent in the practice of educational management in public networks and education systems, such as the continuous teacher training.

\section{Description of the Method Adopted}

To account for the proposed mapping, we organize a quantitative research, accompanied by an analytical-reconstructive methodology, developed of three approaches: the lifting of quantitative data; the content analysis procedure regarding the documentary sources and the literature review.

We used as procedure the longitudinal survey on the main trends of research in teacher training area, over the first fifteen years of the twenty-first century (2001-2015). For this survey, we selected 142 (one hundred and forty-two) scientific articles published in national journals indexed in Qualis the education area (recognition criteria) and also indexed in at least four databases, from the Scientific Electronic Library Online-SciELO (visibility criterion), whereas an indexed article in various bases-libraries and virtual deposits-is able to achieve potentially a greater number of readers. The sample was defined in a non-probabilistic, because the intention was to define the documents examined from previous criteria.

The Qualis was used as recognition criterion for being...

A classification of vehicles for the dissemination of intellectual production (bibliography) of sensu stricto postgraduate programs used by Capes for the reasoning of the assessment of the national postgraduate process promoted by it. It was established in 1998 and has since been used by the Agency for the composition of key indicators for assessing that level of teaching (Documents, 2004: p. 149).

The articles were procedurally selected based on the examination of their titles, abstracts and keywords, when present the expression "teacher training" and/or related terms. Also, the content selection was made from: 1) the centrality of theme (discarded the texts in which the teacher training was not central);2) with reference to the training of teachers for basic education and, 3) journals with a broad scope, which support interdisciplinary articles from different theoretical perspectives and methodological guidelines. 
It is believed that a journal with broad scope is able to show-by the evaluation logic by peers, the general trend of scientific research and not just the issues associated with one or the other thematic área.

Thus, the text presents results of a documentary based research, supported by a literature review and guided by an analytical-reconstructive methodology, focusing on the academic agenda regarding the formation of the Brazilian teacher, having as time cutting the first fifteen years of the twenty-first century. The texts were examined from the content analysis methodology, using the thematic analysis technique, where the "[...] theme is the unity of meaning that emanates naturally from a text analyzed according to criteria relating to the theory that serves at reading guide" (Bardin, 2011: p. 105).

\section{The Results and Discussion}

There, in Brazil, two types of teacher training: initial training and continuing education. Initial training is one that occurs before starting his career, of preparatory way. The continued training of teachers it happens after the beginning of his career.

When discussing teacher education, the main legislation on education in BrazilLaw of Guidelines and Bases of National Education number 9.394, of 1996, has information on: 1) the public obligation to offer teacher training; 2) the shared responsibility for participation a teachers in training process and, 3) the main fundamentals that govern the teaching training (Brazil, 1996: Articles 13, 61, 62, 67 and 87).

The Brazilian educational legislation is therefore specific in regard to teacher education, stating that education systems must promote professional development their teachers (Brazil, 1996: Articles 67 and 87, specifically). So the practice is, in Brazil, a legal condition for the exercise of the teaching profession.

From the political point of view, the investment from LDB 9.394/1996 in teacher education reflects the contextual aspects in which expands of the need for training processes, beyond the legal recognition of the teaching profession and his expertise.

Therefore, the law only expresses a situation real, since "the law is not born from nothing, as inspiration or momentary insight, by desire of this or that; It is the result of a historical process in which actions are developed" (Gatti, 2008: p. 68). And in Brazil, for over twenty years, teacher education is an theme political and academically very discussed.

The issue is considered politically strategic because a well-trained teacher is an actor in the strong sense of the term, that is, a subject who assumes his practice from the meanings that he you gives (Tardif, 2007: p. 23). It is a leading.

The political and strategic relationship between the legislation and the training of teachers can be felt also in other Brazilian laws, such as the National Education Plan, 2014 and the CNE/CP Resolution No. 2, from 1 July 2015, what defines the Guidelines National for initial training at the college level (undergraduate courses, teacher training courses for graduates and second-degree courses) and continuing education.

At being politically strategic, the training teacher also concerns in the academic, re- 
flecting in scientific research and dissemination of the same through scientific articles.

Being important to the academy, the theme resonates in scientific research. Surveys are socialized in magazines of the area and, from that, expands the focus of discussion.

But, what has been researched in Brazil on teacher training? How researchers are positioned? What are the research advances in the area? And gaps potential? To answer these questions, the article searched 142 scientific articles published in the first fifteen years of the twenty-first century in Brazilian journals with a focus on "education".

For the selection of journals we assumed as criteria 1) scientific journals that were in Qualis (https://qualis.capes.gov.br) in education area, in the year 2016; 2) scientific articles indexed in at least four databases, from the Scientific Electronic Library OnlineSciELO (http://www.scielo.org).

Initially the articles were distributed quantitatively by year of publication. In Table 1 we can track the evolution of publications on teacher training. We realize that there not are periods of greater production on the subject. Therefore, theree is certain regularity in the productions on the subject.

At sequence were examined on their content. Starting the data analysis, it is important to mention that, from a quantitative point of view there are thirteen (13) articles with comprehensive scope, thematizing teacher training as a base of discussions with theoretical and conceptual focus. Still eight (8) articles that discuss teacher education in broad themes that allow the combination of the two types of training: initial and continued.

One hundred and twenty-one (121) articles that are left over, are divided into thematizing initial teacher training or continuing teacher training, distributed as follows: 62 articles by discussing the initial teacher training and 59 specifically by discussing the continuing teacher education.

As already mentioned there, Brazil, two levels of education: basic education and higher education. The present Article was dedicated to making the survey of articles that mentioned basic education. However, basic education is divided into three stages: early childhood education, elementary school and high school.

On the steps of basic education, the linear distribution of articles in relation to primary and secondary education was evident: of one hundred and twenty-nine (129) articles specific abaut one stage of basic education (the 8 articles that discuss initial and continuing education, associated with 121 articles that discuss initial or a continuing training), were found forty-two articles on teacher training for action in the early years of schooling and thirty-nine articles on the training of teachers for performance in the

Table 1. Quantitative distribution of articles by year of publication.

\begin{tabular}{|c|c|c|c|c|c|c|c|c|c|c|c|c|c|c|c|c|}
\hline Year & 2001 & 2002 & 2003 & 2004 & 2005 & 2006 & 2007 & 2008 & 2009 & 2010 & 2011 & 2012 & 2013 & 2014 & 2015 & Total \\
\hline $\begin{array}{l}\text { Quantity of } \\
\text { articles per } \\
\text { year }\end{array}$ & 11 & 07 & 11 & 06 & 08 & 07 & 08 & 13 & 12 & 10 & 08 & 09 & 08 & 11 & 13 & 142 \\
\hline
\end{tabular}

Source: Organization of authors. 
final years of schooling, at referred to elementary school. Furthermore, it was found forty-four articles mentioning the training of teachers for performance in high school (final stage of basic education).

However, the distribution of articles is not the same when we mention the first stage of basic education. there is Only four articles thematizing teacher training for early childhood education.

Another perceived absence relates to teacher training-initial or a continuing-to work in private school context. There is only one item registered with the theme. The other articles discuss teacher training for basic public education.

The methodological procedures adopted for the preparation of the articles are multiple: desk research, literature review and case study are the most common procedures. There are also a large number of articles that throw hand autobiographical research, teacher narratives, interviews, academic memorials, focus groups and/or oral history: thirty-eight (38) in total. None article presents a description or application a unique, innovative method on the subject. There are only two articles that used methodological procedures linked to quantitative focus, if both used the Survey.

Regarding the topics covered, one of the recurring themes was the account of innovative experiences in teacher education, and also projects developed in schools or school systems, as projects and experiments in higher education as part of initial teacher education. Of the total articles (129), 68 were dedicated to reporting and analysis of innovative experiences.

Among the articles that describe innovative experiences, 64 of them relate to new approaches to existing practices (courses, workshops, seminars, ...), or provides information on how such practices have been developed in some network or education system. Nonetheless, four articles really they bring different experience in terms of management of teacher training, reporting procedures unpublished, as "traineeships" for teachers.

Yet the content point of view, several authors are directly mentioned in the summaries, including: Francisco Imbernón Muñoz (1952-); Gilles Deleuze (1925-1995); Donald Schön (1930-1997); Jacques-Marie Émile Lacan (1901-1981); Paulo Reglus Neves Freire (1921-1997); Gaston Bachelard (1884-1962); Carl Gustav Jung (1875-1961); Lev Semenovitch Vygotsky (1896-1934); Mikhail Mikhailovich Bakhtin (1895-1975); Dermeval Saviani (1943-); Boaventura de Sousa Santos (1940-); Basil Bernstein (1924-2000) and Michel Foucault (1926-1984).

We realized the massive presence of international authors (only two Brazilians) and the authors with different disciplinary traditions, such as psychiatry, psychoanalysis, philosophy, pedagogy and sociology.

\section{Conclusions}

After having mapped part of the Brazilian scientific production related to teacher training, we reached two conclusions thus arranged: 1) the thematic directions of production and 2) the gaps or absences of issues in scientific production. There is no 
tendency of debate that focuses more on one or the other focus of attention: undergraduate education or continuous teacher training. The articles about one subject or another are balanced in their distribution between the two issues.

However, there are production gaps with regard to teacher training to work in early childhood education as part of the basic education, and as refers the preparation of teachers to work in private schools.

The methodological procedures used to discuss the formation of teachers are primarily qualitative in nature. There is the use restricted or peripheral use of methodologies or quantitative or quali-quantitative approaches.

On the content of articles, we noted a shy presence of Brazilian authors, as well as the indiscriminate use of authors from different theory currents, showing that there is not a line of relatively consensual search for the topic in Brazil.

\section{References}

Almeida, E. C. E. de A., Guimarães, J. A., \& Alves, I. T. G. (2010) Ten Years of Journals Portal Capes: History, Evolution and Use. RBPG, 7, 13, 218-246.

Bardin, L. (2011) Content Analysis (229 p). São Paulo: Edições 70.

Brazil (1996). Presidency of the Republic. Civil House. Subchefia for Legal Affairs. Law 9.394/1996. Establishes the Guidelines and Bases for National Education. http://www.planalto.gov.br/ccivil_03/leis/19394.htm

Brazil CNE/CP No. 2 (2015). It Defines the National Curriculum Guidelines for Initial Training at the College Level (Undergraduate Courses, Teacher Training Courses for Graduates and Second-Degree Courses) and Continuing Education (n. 124, Section 1, pp. 8-12). Brasilia: Official Gazette of the Union, the Executive Branch.

Documents (2004) Capes: Evaluation Board. QUALIS: Design and Basic Guidelines. RBPG. Journal of Graduate Studies.

Gatti, B. A. (2008). Analysis of Public Policies for Continuing Education in Brazil in the Last Decade. Journal Brazilian of Education, 13, 57-70.

Tardif, M. (2007). Teaching Knowledge and Vocational Training (8th ed.). Petrópolis: Vozes.

\section{Submit or recommend next manuscript to SCIRP and we will provide best service for you:}

Accepting pre-submission inquiries through Email, Facebook, LinkedIn, Twitter, etc.

A wide selection of journals (inclusive of 9 subjects, more than 200 journals)

Providing 24-hour high-quality service

User-friendly online submission system

Fair and swift peer-review system

Efficient typesetting and proofreading procedure

Display of the result of downloads and visits, as well as the number of cited articles

Maximum dissemination of your research work

Submit your manuscript at: http://papersubmission.scirp.org/ 